\title{
HIDDEN LOSSES IN FINANCIAL REPORTING AND THE MANNER OF HIDING CASE SERBIA - PART TWO
}

\author{
Nenad Kaludjerovic ${ }^{32}$, Slobodan Stanojevic ${ }^{33}$, Marijana Ljubic ${ }^{34}$
}

\begin{abstract}
There has always been a dilemma whether financial statements are a reflection of the real situation. When financial statements are subject to various conveniences in order to be presented according to the wish of the purchaser, it leads us to the dilemma when and how this happens. This thesis deals with the attempt to start to solve the dilemmas where and when manipulative actions in financial reporting occur. We have carried out researches on selected samples of money losing companies for the period from 2010 to 2013, on the example of financial indicators of the companies which operated in Serbia. Detection of manipulations by means of which loss is hidden in financial statements is very important for the state economy. Under these conditions, development of an adequate method in this area is limited with the international standards of financial reporting. Numerous qualitative and quantitative methods have been used for evaluation of the real and objective components of losses in order to reflect the level of losses in the economy much better. However, in our conditions, there is an universally accepted method which can foresee and evaluate all events and actions that detect hidden losses in financial statements. This thesis presents methods of evaluation (quantitative and qualitative data mining) and how they may be applied in detection of hidden losses in financial statements, by trying to identify a combination of methods which satisfies real needs of a certain task best.
\end{abstract}

KEY WORDS: creative financial statements, hidden losses, qualitative methods, data mining

JEL:M 41, 016

UDC: $657.632(497.11)$

\footnotetext{
${ }^{32}$ Corresponding author, Sofitel Oditordoo, Belgrade, Serbia,e-mail: sofiteloditor@yahoo.com,

${ }^{33}$ Faculty of Applied Management, Economics and Finance,Belgrade, Serbia

${ }^{34}$ John Naisbitt University, Graduate School of Business Studies, Belgrade, Serbia
} 


\section{Introduction}

During the last 4 years we have dealt with financial indicators of the economy of the Republic of Serbia, which were continuously burdened with reported losses as well as with the fact that the net effect of business economy ended with losses at the end of a calendar year. Besides this, it should be added that, during the last 4 observed years (2010-2013), there has been a total of 5029 companies, with total assets over 6.315 million euros, which went bankrupt. The report on the economy of the Republic of Serbia and comparative indicators for the period from 2010 to 2013 indicate a dramatic downfall of the total economic activity, followed by reduction of financial independence. Such condition of economic activity resulted in reduction of the rate of employment. Namely, Serbia belongs to the group of countries with the highest rate of unemployment, and it precedes in Europe with the highest cumulative rate of inflation and the lowest rate of total investments. Losses of Serbian economy record the growth of 12.260 million euros in 2010, through a projected loss up to 4.716 million euros in 2012, while this loss is smaller in 2013, amounting to 4.115 million euros. However, it should be analyzed separately whether these disclosed data show real losses or more precisely business effects, this is, positive or negative financial results (loss or profit). The reason for this lies in the fact that, according to the methodology of detection, positive or negative financial result also comprises the elements of creative combinations, which enable the employers to postpone the truth about business situation and give them the possibility to mislead other financial institutions. This is why we have devoted ourselves to these researches, in order to detect where this manipulation, this is creativity in financial reporting, occurs. Hidden losses affect macroeconomic factors and they depend not only on these factors (market, business dealings and legislature), but also on microeconomic factors (resources, quality of production, organization, management motives, business environment, political environment etc.) at the same time. In this research, we have tried to detect those factors of losses which are not visible, precisely, which are hidden in financial statements and which affect proper expression of business results (net profit - money earning companies or net loss money losing companies). We have tried to find out where manifestation form of hidden losses appears in financial statements and where it is annulled or hidden in a manipulative way. Hiding through various forms of financial reporting belongs to manipulative methods, by which reporting of negative business effects is postponed (if a business entity is a money losing company) or fictitous positive effects simulated (if a business entity is a money earning company). Such practice, which became domesticated, left significant consequences on Serbian economy. It is well known that business entities with losses and big assets were liquidated summarily and creditors mostly damnified in economic transformations of the Republic of Serbia, due to financial deregulation. The proof of taking such measures is frequent bankruptcies. The phenomena of continuous losses, evaluation of general causes of their occurence and their appearance are not analyzed professionally enough. This thesis deals exactly with detection of hidden losses, by revealing manipulative (qualitative) and quantitative (hereinafter referred to as Data Mining DM) methods of detection of hidden losses, with special emphasis to analysis of characteristics of losses in private and public sector. As a material for this researches, we have used the sample of 1000 companies, 500 money losing companies and 500 money earning companies, thereby taking care to include small, medium and big companies as well as to comprise companies of different organizational form (limited liability companies, joint-stock companies, public enterprises and other companies). The subject of observation are financial statements for 2010 , 2011, 2012 and 2013. 


\section{Methodology of research}

The method of research will be represented in that way that analysis of ratio indicators will be conducted on the selected samples and these ratio indicators will be observed in the context of data mining analysis at the same time. If it is found out that the data obtained in one method of analysis will be valid for another method as well, the category of financial statement which changes business result significantly will be evaluated. Besides the selected method of sampling, key indicators which affect the financial result will be taken into consideration. We will join such indicators in the context of actually associated indicators and through such manner of correcting of the selected financial statements we will conduct other analysis through ratio indicators and Data Mining - DM.

\section{Data from the sample and their representation in total data}

Table 1: Overview of Cash earnings of companies (Review 1)

\begin{tabular}{|c|c|c|c|c|c|}
\hline \multirow[b]{2}{*}{$\begin{array}{l}\text { Financial } \\
\text { statement: }\end{array}$} & \multirow[b]{2}{*}{ Type of indicator } & \multicolumn{4}{|c|}{ Year: } \\
\hline & & 2010 & 2011 & 2012 & 2013 \\
\hline for economy & $\begin{array}{l}\text { Number of companies in Serbia } \\
\text { which submitted and registered } \\
\text { financial statements }\end{array}$ & 95002 & 107363 & 106539 & 94362 \\
\hline \multirow[t]{2}{*}{ sample } & Number of (companies) samples & 508 & 501 & 501 & 500 \\
\hline & - $\quad \%$ of sample share & $0,53 \%$ & $0,47 \%$ & $0,47 \%$ & $0,53 \%$ \\
\hline for economy & $\begin{array}{l}\text { - Total financial profit in Serbia } \\
\text { according to submitted reports } \\
\text { in million euros }\end{array}$ & $3.054 €$ & $4.382 €$ & $3.803 €$ & $3.108 €$ \\
\hline \multirow[t]{3}{*}{ sample } & Presented profit in million euros & $2.203 €$ & $2.471 €$ & $2.776 €$ & $2628 €$ \\
\hline & - $\quad \%$ of sample share & $72,13 \%$ & $56,38 \%$ & $73,01 \%$ & $84.56 \%$ \\
\hline & & & \multicolumn{3}{|c|}{ Губитаи } \\
\hline sample & \multirow{3}{*}{$\begin{array}{l}\text { Number of (companies) samples } \\
-\quad \% \text { of sample share } \\
-\quad \text { Total financial loss in Serbia } \\
\text { according to submitted reports } \\
\text { in million euros }\end{array}$} & 508 & 501 & 501 & 500 \\
\hline & & $0,53 \%$ & $0,47 \%$ & $0,47 \%$ & $0,53 \%$ \\
\hline for economy & & $4.016 €$ & $3.572 €$ & $3.476 €$ & $1.738 €$ \\
\hline \multirow[t]{2}{*}{ sample } & & $544 €$ & $2.813 €$ & $3.310 €$ & $342 €$ \\
\hline & $\begin{array}{l}\text { - } \quad \text { Presented loss in million euros } \\
\text { _ } \quad \% \text { sample share }\end{array}$ & $13.55 \%$ & $78.76 \%$ & $95.21 \%$ & $19.68 \%$ \\
\hline
\end{tabular}

Source: Authors

We have conducted the analysis of business results, this is detection of hidden losses as well as the manners of losses or profit production applying qualitative and DM methods, based on the selected sample of financial statements: Balance Sheet and Profit and Loss Account. The primary data are taken from business results (net profit in relation to net loss) and elements of financial results (balance accounts and ratio indicators), which were presented in the report on the economy of the Republic of Serbia in 2010, 2011, 2012 and 2013, published by the Republic Business Registers Agency on its website (www.apr.gov). The selected sample of 95002 companies, which is the total number of registered companies operating in the Republic of Serbia, reported the profit 
of 3803 million euros, while the profit of 2203 million euros was analyzed in the sample of 508 money earning companies, which is $72,13 \%$ for 2010 .

The selected sample of 107363 companies, which is the total number of registered companies operating in the Republic of Serbia, reported the profit of 4382 million euros, while the profit of 2471 million euros was analyzed in the sample of 501 money earning companies, which is $56,38 \%$ for 2011 .

The selected sample of 106539 companies, which is the total number of registered companies operating in the Republic of Serbia, reported the profit of 3054 million euros, while the profit of 2628 million euros was analyzed in the sample of 500 money earning companies, which is $73,01 \%$ for 2012 .

The selected sample of 94362 companies, which is the total number of registered companies operating in the Republic of Serbia, reported the profit of 3108 million euros, while the profit of 2203 million euros was analyzed in the sample of 508 money earning companies, which is $84,56 \%$ for 2013 (Review no.1).

It is evident that the number of companies in the sample is insignificant, for example, $5 \%$ for 2012, while value indicators for the sample, in relation to population of the companies in Serbia, are represented with about $74 \%$. Value indicators of money losing companies are represented with $96 \%$, this is $19,68 \%$ in 2013 , which indicates that there are few companies being the key generator of the loss of Serbian economy.

\section{Variables}

We have divided the most significant features which we used in this analysis in two groups. The first group of features consists of the data reported in financial statements: balance accounts, to which we added total turnover due to more precise loss analysis, namely: other incomes, other expenses, financial incomes, financial expenses, summarized material expenses which are reported in financial statements as well as unproductive costs. Another group of variables consists of the results obtained from ratio analyses, such as: EBIT, income on working capital, net result rate before taxation, number of days of payment, reduced liquidity ratio, contribution margin etc.

\section{Methods}

We have analyzed the identification of hidden losses by applying two methods: qualitative and quantitative. From the aspect of qualitative method, it has to be pointed out that a dominant component is expert reasoning, acquired from a decades-long practice in the domain of commercial, public sector and forensic accounting and auditing. By the method of reasoning, key balance accounts and circulation indicators, which are mostly significant for detection of hidden losses of Serbian economy, have been determined. Application of quantitative methods is based on the application of discovering of hidden, this is, submerged knowledge in the data (Data Mining). The technique of classification, which is conducted through supervised machine learining, is typical for these methods as well as classification of relevant features which determine losses versus profit of the company. 


\section{Qualitative loss analysis}

Qualitative methods of detection of losses are based on the evaluation of the researcher and they don't differ procedurally from the auditor's reasoning which is based on practice and experience. In the procedure of qualitative analysis, dominant factors are normativedescriptive analysis of data and descriptive statistics, which are based on detection of the structure of losses and on validity of the structure of incomes and expenses, which is the subject of the next part of the reivew.

\section{Structure of loss according to the size and organizatinal form of the company}

In the analysis of the structure of loss according to the size of the company (small, medium and big companies) we start from the effects of results (loss versus profit on the macro level) on the level of economy, through the effects of results between total reported profit and loss. The obtained negative business effect of 862 million euros in 2010 was significantly restored already in 2011 and 2012, while in 2013 this effect was significantly manifested and reported in the amount of 1370 million euros (Review no. 2).

Table 2: Overview amount of loss according to the size and shape of organizing companies(Review 2)

\begin{tabular}{|c|c|c|c|c|}
\hline \multirow{2}{*}{$\begin{array}{c}\text { Amount of loss according to the size and } \\
\text { organizational form of the company } \\
\text { Description/years }\end{array}$} & \multirow[b]{2}{*}{2010} & \multicolumn{3}{|c|}{$\begin{array}{l}\text { Review no. } 2 \\
\text { In million euros/ }\end{array}$} \\
\hline & & 2011 & 2012 & 2013 \\
\hline 1.Net loss & $4.016 €$ & $3.572 €$ & $3.476 €$ & $4.115 €$ \\
\hline 2.Net profit & $3.054 €$ & $4.382 €$ & $3.803 €$ & $3.912 €$ \\
\hline Effects of results (1-2) & $(962)$ & 810 & 327 & $(200)$ \\
\hline Losses according to the size of the company: & & & & \\
\hline$-\quad$ Small & 1.285 & 1.314 & 1.460 & 1.113 \\
\hline - $\quad$ Medium & 845 & 666 & 648 & 569 \\
\hline Big & 1.886 & 1.798 & 2.248 & 2.443 \\
\hline $\begin{array}{l}\text { Total loss according to organizational form of } \\
\text { the company: }\end{array}$ & $4.016 €$ & $3.572 €$ & $3.476 €$ & $1.738 \epsilon$ \\
\hline - $\quad$ Limited liability companies & 2.501 & 2.292 & 2.434 & 2195 \\
\hline - Joint-stock companies & 901 & 1.259 & 1.284 & 1424 \\
\hline - $\quad$ Public enterprises & 327 & 160 & 536 & 52 \\
\hline$-\quad$ Other & 123 & 67 & 101 & 444 \\
\hline Total loss according to legal form: & $4.016 €$ & $3.572 €$ & $3.476 €$ & $4.115 \epsilon$ \\
\hline
\end{tabular}

\section{Source:Authors}

What is evident is the fact that losses on the level of the Republic of Serbia were always kept in the amount of 4016 million euros in 2010, while these losses amounted to 4115 million euros in 2013. A negative business effect, amounting to 200 million euros (Review no. 2) appears again in 2013. Such state of data, from the standpoint of loss, leads us to determine which category of the loss is so dominant that it significantly corrects the amount of loss. Losses should be observed from the standpoint of structure of their origin. For the purpose of our reseraches, we have decided to observe them through net effects of financing and effects of other incomes versus other expenses. 


\section{Manipulating with the effects of financing}

Serbian Business Registers Agency (SBRA) disclosed that a negative financial effect of small companies for a given period (Review no. 3) amounted to 645 million euros in 2010, while this amount increased to 1030 million euros in 2013. The cause of such oscillations of financial effects are differences between granted and received interest rates and currency depreciation of credit debts as well as the interest rate for untimely servicing of liabilities and receivables. Limited liability compaines had a negative financial effect amounting to 1.372 million euros in 2010, while they reported a positive financial effect in 2011 and 2012, and in 2013 they had a negative financial effect again, amounting to 680 million euros.

Table 3: Overview Net financial effect (Review no.3)

\begin{tabular}{||llrrr|r||}
\hline & Net financial effect & \multicolumn{4}{c|}{ In million euros/Review no.3 } \\
& 2010 & 2011 & \multicolumn{1}{c||}{2012} & \multicolumn{1}{c|}{2013} \\
\hline- & Small companies & $(290)$ & $(13)$ & $(398)$ & $(281)$ \\
- & Medium companies & $(49)$ & 68 & 72 & $(202)$ \\
- & Big companies & $(305)$ & 558 & $(226)$ & $(547)$ \\
& $\quad$ Effects of results & $\mathbf{( 6 4 5 )}$ & $\mathbf{6 1 3}$ & $\mathbf{( 5 5 2 )}$ & $\mathbf{( 1 0 3 0 )}$ \\
- & Limited liability & $(1.372)$ & 751 & 271 & $(680)$ \\
& companies & 756 & $(62)$ & $(303)$ & $(243)$ \\
- & Joint-stock companies & $(29)$ & $(72)$ & $(479)$ & $(103)$ \\
- & Public enterprises & & -3 & -41 & $(4)$ \\
- & Other & & $\mathbf{6 1 3}$ & $\mathbf{( 5 5 2 )}$ & $\mathbf{( 1 0 3 0 )}$ \\
\hline
\end{tabular}

\section{Source:Authors}

According to the report of SBRA (Review no. 4) for 2010, 2.483 companies went bankrupt, while this number increased to 5029 companies in 2013 , which is $4 \%$ more bankruptcies of companies in relation to 2012. On the average, 400 to 600 companies go bankrupt per year(http://www.alsu.gov.rs/bap/code/navigate.jsp?Id=200). The biggest number of liquidated companies and closed bankruptcies refers to limited liability companies. Liabilities (long-term, shortterm and accrued costs) of the companies for which the procedure of bankruptcy or liquidation was started ranged from 4.042 million euros in 2010 , while they were brought down to 3477 million euros in 2013. The important dilemma for these researches is how liabilities of the companies under liquidation are manifested on the total assets of business companies which operate regurarly.

Table 4: Overview Number of established and liquidated companies in Serbia

\begin{tabular}{||lrrrr||}
\hline \hline Number of established and liquidated companies in & \multicolumn{4}{c||}{ Review no. 4 } \\
\cline { 2 - 5 } Serbia & 2010 & 2011 & 2012 & 2013 \\
\hline Newly established business companies per years & 7792 & 7260 & 7076 & 7004 \\
\cline { 2 - 5 } & $\mathbf{2 4 8 3}$ & $\mathbf{2 8 5 2}$ & $\mathbf{4 8 3 7}$ & $\mathbf{5 0 2 9}$ \\
Value expressed in million euros: & & & & \\
- Total receivables of liquidated companies: & 530 & 517 & 1.413 & 300 \\
On the basis of financial investments: & 330 & 320 & 560 & 443 \\
$-\quad$ Total liabilities of liquidated companies: & $\mathbf{4 . 0 4 2}$ & $\mathbf{3 . 7 2 5}$ & $\mathbf{2 . 7 2 2}$ & $\mathbf{3 . 4 7 7}$ \\
\hline
\end{tabular}

Source: Statistical bulletin of economic trends in Serbia and data of NBS published in reports for 2010,2011, 2012 and 2013 
We haven't found the information that the given investments of the companies under liquidation were written-off. This phenomenon of hiding of investments by the companies under liquidation makes additonal negative implications in financial reporting of the companies which submit real financial statements. In our case, the write-off of short-term financial investments for liquidated companies was not registered completely in financial statements. This phenomenon represents the element which affects validity of financial statements. Business entities entered the write-off of finanical investments for the given companies only when financial effect left them enough space for reporting a positive financial result in financial statements. In our analysis, we have found out that, if money earning companies wrote-off the investments completely, they would become money losing companies, which would be a warning for creditors to take measures in order to protect their receivables. This means that the companies, which had debts on the basis of negative finanical effects and losses in business, had to declare bankruptcy or start liquidation earlier. In this way bankruptcy was delayed as losses were hidden through artificial, positive business effects. Negative financial effects would be increased anyway for the above given receivables which were not entered in financial statements. The implication of such tendency is that negative financial effects of limited liability companies (in our case) were not reported. Jointstock companies and public enterprises reported negative financial effects in 2012, but the amount of 303 million euros was far less than the amount of joint-stock companies (of open and closed type), while negative financial effects of public enterprises were about 479 million euros and this amount was reduced to 103 million euros in 2013.

This has been explained through the selected, tested samples, where financial income of money earning companies increased from 1.000 million euros in 2010 to 1.030 million euros in 2012 and 1425 million euros in 2013. The same tendency has been noticed in financial expenses. The structure of financial income consists of interest rates obtained from long-term and short-term investments, interest rates from liabilities, interest rates from court judgements, positive foreign exchange differences etc. We have not found the write-offs of financial investments anywhere in the structure of financial expenses, either in the tested sample or in the official reports.

This is why we have made a simulation of the financial statement on the tested sample, in order to see what will happen with the financial result when we add the write-off of investments, which were given to companies before the procedure of bankruptcy was started, to financial expenses. In the selected samples of tested companies the dynamics of growth of financial expenses is bigger than financial income in terms of value, which makes a negative financial effect (Review no. 5) both for money earning companies and money losing companies. Namely, financial effects are negative both for money earning companies and money losing companies. Financial effects show financial income and expenses which could not be delayed due to bank obligations, so that they were entered in financial reports more often for the purpose of further cost projection, through the selective write-off of liabilities or receivables, in order to eliminate or mitigate negative financial effects of money earning companies. In the Review no. 5, it can be seen that business companies, this is money earning companies, had to write off financial investments of liquidated companies. Unfortunately, they haven't entered such type of change in their business books. Therefore, a negative financial effect of money earning companies, amounting to 353 million euros in 2010, should be increased for 330 million euros on the basis of the write-off of investments. The same goes for 2011, where negative financial effect should be increased for 320 million euros, in 2012 for 560 million euros and in 2013 for 443 million euros. The expenses which have been identified subsequently through our simulations on the basis of the write-off of investments 
confirm that distorted image was shown in financial statement. This simply means that these indicators will be manifested differently in ratio indicators as well. Therefore, the liquidity ratio which is represented with the coefficient of 0,89 in the total official data will have to replace the liquidity ratio after the write-off of investments with the coefficient of 0,02 . This will enable presentation of real liquidity of a company in financial statemets.

Table 5: Review of amount of loss in the bserved sample of 500 money losing companies (realiyed financial effects)

\begin{tabular}{|c|c|c|c|c|c|c|c|c|}
\hline \multirow{2}{*}{\multicolumn{5}{|c|}{$\begin{array}{l}\text { Review of amount of loss in the observed sample of } 500 \text { money earing and } 500 \text { money } \\
\text { losing companies (realized financial effects) Money earning company }\end{array}$}} & \multirow{2}{*}{\multicolumn{4}{|c|}{$\frac{\text { In million euros/Review no. } 5}{\text { Money losing company }}$}} \\
\hline & & & & & & & & \\
\hline Position/Year & 2010 & 2011 & 2012 & 2013 & 2010 & 2011 & 2012 & 2013 \\
\hline Financial income: & 1.000 & 1.071 & 1.030 & 1425 & 194 & 669 & 825 & 986 \\
\hline Financial expenses: & 1.353 & 1.080 & 1.263 & 982 & 762 & 1.409 & 2.037 & 2088 \\
\hline Financial effect : & $\begin{array}{l}-353 \\
\end{array}$ & -9 & -233 & & +568 & $\begin{array}{l}-740 \\
\end{array}$ & -1.212 & -1102 \\
\hline $\begin{array}{ll}- & \text { Financial liabilities on the basis of } \\
\text { investments for liquidated companies } \\
\text { (unrecorded write-off) for the write-off : }\end{array}$ & -330 & -320 & -560 & -443 & & & & \\
\hline $\begin{array}{ll}- & \text { Amount which is not entered in financial } \\
\text { expenses for joint-stock companies }\end{array}$ & & & -433 & 12 & & & & \\
\hline (*) Corrected financial effect & -330 & -320 & -993 & -445 & & & & \\
\hline & & & & & & & & \\
\hline
\end{tabular}

\section{Sourse :Authors}

In this case, elements of manipulation are expressed through unreported write-off of financial investments of liquidated companies. In our case, it is the amount shown in the Review no. 5 through corrected financial effect.

\section{Manipulation with the effects of extraordinary income and expenses}

Table 6: Review of amount of loss in the observed sample of 500 money earing and 500 money losing companies

\begin{tabular}{|c|c|c|c|c|}
\hline \multirow{2}{*}{$\begin{array}{l}\text { Effects of other expenses on } \\
\text { the level of economy. } \\
\text { Review } 6\end{array}$} & \multicolumn{4}{|c|}{ In million euros } \\
\hline & 2010 & 2011 & 2012 & 2013 \\
\hline small companies & (231) & (206) & (402) & -292 \\
\hline medium companies & (17) & (95) & (95) & -123 \\
\hline big companies & (359) & (182) & (957) & $(1425)$ \\
\hline Total: & $(607)$ & (483) & (1.454) & $(1840)$ \\
\hline $\begin{array}{ll}\text { - } & \text { Limited liability } \\
\text { companies }\end{array}$ & $(512)$ & $(255)$ & $(235)$ & $(246)$ \\
\hline Joint-stock companies & 3 & (131) & $(120)$ & (16) \\
\hline Public enterprises & (88) & (95) & (87) & (761) \\
\hline Other entities & (10) & (3) & (1.012) & $(817)$ \\
\hline Total: & $(607)$ & (483) & $(\mathbf{1 . 4 5 4 )}$ & $(\mathbf{1 . 8 4 0 )}$ \\
\hline
\end{tabular}

\section{SourseAuthors}

The next segment of detection of hidden featuress of losses can be found in the effects of regular income and expenses (Review no. 6). Although the correction of business results by extraordinary income or expenses is always present in financial statements in Serbia, its 
significance depends mostly on the management policy and even on the national regulations, when the difference between the profit from the last and current period is not enough to cover the total reported negative financial effects in the current year, which also comprise other losses of other entities. However, this phenomenon is characteristic for money earning companies as well. In our selected sample, the reported negative effect of business results amounts to 789 million euros (Review no. $2 ;=962$ million euros in $2010+810$ million euros in $2011+327$ million euros in 2012 and minus - 200 million euros in 2013), which makes 6,7\% of the total income, while on the level of the whole Serbian economy financial effect is represented with 3,5\% (NBS,2010,2011,2012,2013).

On the level of economy, the effects of extraordinary income and expenses have been analyzed collectively for money earning companies and money losing companies. A negative effect of extraordinary income and expenses (Review no. 6) has been reported in financial statements of big companies in the amount of 359 million euros in 2010, while it was 957 million euros in 2012, and in 2013 it increased cumulatively to the amount of 1425 million euros. This phenomenon is not random, but it is the result of our confirmed research, that the companies had to correct business results in 2013 by means of additional write-offs of investments, which can be seen best in financial statement of big companies. Speaking of small companies, a negative effect of extraordinary income and expenses was 231 million euros and it was reduced to 292 million euros in 2013. Limited liability companies had a negative effect of extraordinary income and expenses of 512 million euros in 2010, while their financial statements show that this amount reduced to 246 million euros in 2013. The effects of extraordinary income and expenses increased significantly, amounting to 817 million euros in 2013. The most dominant implications of this effect can be seen in public enterprises, which were liquidated or for which bankruptcy procedure was started. Extraordinary income and expenses have become the device which may affect managing of business results. This way of manipulation cannot be perceived directly, but the data we have analyzed showed that this phenomenon is a frequent and conscious activity by which financial statements are manipulated. Other expenses hide creators of loss in themselves, as they are an important element of manipulating and determining the direction of effects. In order to check this, we have tested a simulated person, who had to decide what he will enter as an extraordinary income and what as an extraordinary expense. In the data which we have analyzed (Review no. 7), financial effects are negative in the case of the money earning company. The most important item in extraordinary income is the write-off of liabilities to suppliers, although they supplied the goods or service, from which the company received income and entered it in regular financial statements. We deal with this accounting correction of the write-off of liabilities because this is where the so-called creative accounting is applied. This means that it represents the moment of manipulating with the outcome in financial operations, through result fixing, so that it does not reflect the real situation. By removing, this is, writing off of liabilities to suppliers, we have got the implication that a negative business effect based on an extraordinary income has the tendency of growth, both for money earning companies and money losing companies. Simply said, a manipulative action of removing of data on an extraordinary income was performed. The obtained negative effect of loss for 2010, amounting to 487 million euros and for 2011, amounting to 1.755 million euros, point out that the minimum loss will be 2.261 million euros in the coming years. In this case, profit from regular business will increase from 1.137 million euros in 2010 to 2.043 million euros, which will result in a negative business effect of 487 million euros in 2010 to 2.261 million euros in 2012. Analyzing the sample, by removing the written-off liabilities 
from extraordinary expenses, we got the situation in which business effects were negative exactly for the amount of extraordinary income.

Table 7: Review of correction of effects of results based on removing of extraordinary income in the observed sample of 500 money earning companies and 500 money losing companies and their financial effects

\begin{tabular}{|c|c|c|c|c|c|}
\hline \multirow[t]{2}{*}{$\begin{array}{c}\text { No } \\
.\end{array}$} & $\begin{array}{c}\text { Review of correction of effects of results based on } \\
\text { removing of extraordinary income in the observed sample } \\
\text { of } 500 \text { money earning companies and } 500 \text { money losing } \\
\text { companies and their financial effects }\end{array}$ & \multicolumn{4}{|c|}{ Money earning company /Review no. 7} \\
\hline & Position / year & 2010 & 2011 & 2012 & 2013 \\
\hline 1 & Business income & 21,822 & 21,755 & 23,369 & 19,256 \\
\hline 2 & Business expenses & 19,669 & 19,638 & 20,384 & 19,158 \\
\hline 3 & Business profit & 2,153 & 2,117 & 2,985 & \\
\hline 4 & Business loss & 50 & 157 & 32 & 902 \\
\hline 5 & Financial income & 1,000 & 1,071 & 1,030 & 1,425 \\
\hline 6 & Financial expenses & 1,353 & 1,080 & 1,263 & 982 \\
\hline 9 & Other income & 452 & 389 & 350 & 898 \\
\hline 10 & Other expenses & 663 & 843 & 1,708 & 358 \\
\hline 11 & Profit from regular business before taxation & $\underline{1,539}$ & $\underline{1,497}$ & $\underline{1,362}$ & $\underline{81}$ \\
\hline 12 & $\begin{array}{ll}\text { Extraordinary write-off based on creditors } \\
\text { liquidation: }\end{array}$ & -330 & -320 & -560 & -443 \\
\hline 13 & Loss from regular business before taxation & 0 & 0 & 57 & 68 \\
\hline \multirow{2}{*}{\multicolumn{2}{|c|}{$\begin{array}{l}\text { Effect of results (Profit from regular business - loss from regular } \\
\text { business (correction-consequence of the manipulation) }\end{array}$}} & 1,209 & 1,177 & 802 & -362 \\
\hline & & -330 & -320 & $\underline{-560}$ & -443 \\
\hline
\end{tabular}

\section{Source: Authors}

As we have mentioned previously, an extraordinary income mostly appears based on the write-off of liabilities to suppliers (No. 9 of the Review no. 7). The write-off of liabilities to suppliers is the phenomenon that is present, but only when it has its real essence. This means that all legal, time and material conditions have been met to apply the write-off and report its effects in financial statements, which is not the practice in most cases.

We have tried to determine the fate of all purchased goods and services, based on which a liability to suppliers occured and which became an operating extraordinary income upon liquidation of the creditor. This write-off is covered from liquid funds, but they can go in other direction as well, which is the subject of a separate analysis - detection of money laundering mechanisms.

\section{Application of quantitative methods - Data Mining}

Data Mining (DM) is a method of the interactive process of detecting relations and models manually or automatically. The essence of DM is that the research process scenario is not based on pre-defined hypotheses which constitute the „required " results (Kantardzic, 2002). We are of the opinion that such methodological design of the domain of application of DM is significant for detection of hidden losses, this is financial classification of business entitites into money losing companies and money earning companies. We have not used the application of DM method for prediction of losses or profit, but for determining of certain ratio indicators which affect losses significantly. 
In the domain of application of DM, identification of hidden losses in financial statements is a typical problem of classification, which consists of two procedures. In the first procedure, the model is learned by application of the trained sample (supervised learning), while in the second procedure the samples are classified into those which belong to a determined set or which do not belong to this set, as the final phase of variations of accuracy of results.

\section{Table 8: Ratio indicators}

Features: 30

\begin{tabular}{|c|c|}
\hline $\begin{array}{ll}\text { 1. } & \text { General liquidity ratio } \\
\text { 2. } & \text { Reduced liquidity ratio } \\
\text { 3. } & \text { Cash liquidity ratio } \\
\text { 4. } & \text { Business assets turnover ratio } \\
\text { 5. } & \text { Fixed assets turnover ratio } \\
\text { 6. } & \text { Current assets turnover ratio } \\
\text { 7. } & \text { Supply turnover ratio } \\
\text { 8. } & \text { Days turnover ratio } \\
\text { 9. Liability turnover ratio } \\
\text { 10. Number of days of collection } \\
\text { 11. Working capital turnover ratio } \\
\text { 12. Turnover ratio of liabilities to } \\
\text { 13. Nuppliers } \\
\text { liabilities to suppliers } \\
\text { 14. Level of use of fixed assets plus } \\
\text { 15. Level of use of working assets plus } \\
\text { long-term resources }\end{array}$ & $\begin{array}{l}\text { 16. Level of coverage of supplies and } \\
\text { accrued receivables with net working } \\
\text { capital } \\
\text { 17. Involvement of working capital in } \\
\text { long-term resources } \\
\text { 18. Contribution margin } \\
\text { 19. Business result rate } \\
\text { 20. Net result rate before taxation } \\
\text { 21. Net result rate } \\
\text { 22. Income on commercial property } \\
\text { 23. Income on working capital } \\
\text { 24. Duration of business cycle } \\
\text { 25. Duration of cash conversion cycle } \\
\text { 26. EBITDA } \\
\text { 27. EBIT } \\
\text { 28. Financial result } \\
\text { 29. Other results } \\
\text { 30. Class }\end{array}$ \\
\hline
\end{tabular}

\section{Decision Tree learning method (Decision Trees, DT)}

Decision Tree learning is a process of creation of discriminatory function in the form of decision trees (Cherkassky et al., 2005). The tree is created recursively, from the top (root) to the leaves, so that every knot of the tree represents a logical test of value of certain feature from the description of the problem, while leaves represent the class into which the example is classified. During creation, the choice of features for every knot is done by heuristic methods, based on evaluations of quality discrimination of the (sub)set of examples from the training set, which have remained to be discriminated in the observed knot. Although the tree may classify all examples from the training set perfectly, this is not a guarantee of high accuracy for new examples, as they are often overfit to training examples. Due to this, they are simplified in practice, giving smaller trees, which are more precise and comprehensible at the same time. In our analysis, we have used the well-known algorithms of decision tree learning, namely C4.5 (Quinlan J. P., 1996)), which are available within the WEKA (University of Waukamo) (Witten et al., 2005), in order to select the related features. The main advantage of the decision tree is its significant manner of knowledge representation through the extraction IF-THEN of classification rules. 


\section{Learning method of production rules (Rule Learning, RL)}

Production rules are logical expressions of implications forms, by which classification of examples into one of the provided classes is done based on the known values of features. (Cherkassky V., Mulier F. M., 2007, Witten I. H., Frank E., 2005). The set of rules is more often created by the method of version spaces or by division of the training set on subsets (separate and conquer) and their description by means of logical expressions, which may be propositional (without quantifiers) or predicative (first order or, exceptionally, higher orders). Likewise the decision tree, the learned set of rules does not need to describe training examples perfectly. A special variant is decision lists, where the rules are used sequentially (the wellknown example of algorithms of learning of propositional rules is RIPPER (Forsyth R. (ed), Machine Learning: Principles and technics, London: Chapman and Hall, 1989.), which are available within the WEKA system).

\section{Selection of features}

Forming of an adequate model is done based on the foreknowledge of the problem and it is often brought down to the selection of an adequate set of features. The existence of irrelevant and redundant (inessential, unnecessary) features in the model of a problem has a negative effect on the performances of most methods of inductive learning, and therefore such features are not often taken into consideration owing to previous or built-in feature selection (Cherkassky V., Mulier F. M., 2007, Witten I. H., Frank E., 2005). The optimal set of features contains all relevant features, while redundant and irrelevant features are usually not taken into consideration, although these irrelevant and redundant features potentially contain information which may have an impact on improving of classification performances in practice (Cherkassky V., Mulier F. M., 2007.). In the review, we will use some methods of previous selection of features, which were built in the WEKA system (Witten I. H., Frank E., 2005., Maindonald J., Braun J., 2007.), for additional check of the importance of certain features from the problem model.

\section{Data - ratio indicators}

From the integral sample based on which quantitative analysis has been conducted, all four years were taken - from 2010 to 2013, with the ratio about 50\%:50\% of money earning companies and money losing companies respectively. The sample contains 3457 entities companies which have been classified using 29 features - ratio indicators and the target feature „Class "with two values, for money earning company and money losing company respectively (Review 1). For the purpose of the functional analysis, ratio indicators have been evaluated from the aspect of binary classification (for example, favourable with 1 and unfavourable with 0 , this is, unfavourable general liquidity ratio $<1$ with 0 and favourable general liquidity ratio $>0$ with 1 ). Thus binary classified features have presented the influence of ratio indicators on loss or profit of the observed entities - business companies and budget users. In this enclosure, three above mentioned Data Mining methods have been applied, namely Decision Tree-DT, Rule Learning-RL and Feature Selection. 


\section{Results of the analysis}

As mentioned above, we have applied three alternative models. Firstly, Decision Tree by application of the WEKA (University of Waikato), Tanagra (Ricco RAKOTOMALALA) and Sipina Research Edition software - learning trees C45. The model has been made with the confidence interval of 0,05 . We have used the whole sample as a training set. One decision tree has been obtained, this is, the structure IF-THEN of classification rules (Figure 1). The model has been tested in relation to the training set and it has classified correctly money earning companies with the accuracy of $96 \%$ and money losing companies with $96 \%$ as well.

As we can see in the Figure 1, the algorithm has found a splitter feature EBIT ratio indicator.

- $\quad \mathrm{EBIT}=0$

Income on working capital $=0$

- Net result rate before taxation $=0$

- $\quad$ Financial result $=0$

- $\quad$ Other results $=0$ then Class $=$ MONEY LOSING

COMPANY (96.05\% of 886 examples)

- $\quad$ Other results $=1$

- Level of use of fixed assets plus working capital = 0 then Class $=$ MONEY LOSING COMPANY (70.15\% of 67 examples)

- Level of use of fixed assets plus working capital = 1 then Class = MONEY EARNING COMPANY (76.97\% of 59 examples)

- $\quad$ Financial result $=1$ then Class $=$ MONEY EARNING COMPANY (69.49\% of 59 examples)

- $\quad$ Net result rate before taxation $=1$ then Class $=$ MONEY EARNING COMPANY (100.00\% of 92 examples)

O Income on working capital $=1$ then Class $=$ MONEY EARNING COMPANY $(99.26 \%$ of 135 examples)

- $\quad \mathrm{EBIT}=1$ then Class $=$ MONEY EARNING COMPANY $(99.20 \%$ of 1004 examples $)$

More specific, the decision tree has identified with the accuracy of $96 \%$ that classification in money earning companies and money losing companies was based on the EBIT ratio indicator, whose structure was determined by the following elements: profit before taxation + financial expenses (costs of interest rates) + Taxes. This means that, if this index is favourable, this is, if it equals1 (EBIT=1), 1.004 money earning companies are clearly classified $(99,20 \%)$.

If EBIT equals 0, this is, if it is unfavourable, then the decision tree branches out into the following sequence of negative indicators - if Income on working capital (Net profit rate*working capital turnover ratio) $=0$ and if Financial result (Financial income - Financial expenses) $=0$ whereas Other results (Other income - Other expenses) $=0$, then 968 money losing companies which generate about $40 \%$ of money losing companies are classified.

Namely, due to manipulative actions in financial reporting, total liabilities are reduced by subsequent write-off of business liabilities, which gives distorted image in the evaluation of involvement of working capital in long-term and short-term resources, as resources are reduced and profit corrected in total sum due to the fact that a significant part of the result is negative (especially in 2012 and $2013 \Rightarrow$ Review no.7). Therefore, operating profit is never final, as negative financial effects, this is, consequences of manipulating with the financial statement undermine it. Application of the method of inductive rules 
The second method which has been used is the method of learning of RIPPER rules from the WEKA system, which has found logical patterns, this is, which has learned 4 rules, with a significant number of counter examples from the training set. The estimated accuracy of the sets of rules is $96,6 \%$ of the accuracy of the priori classification.

JRIP rules:

1. $($ EBIT $=0)$ and (Number of days of payment of liabilities to suppliers $=1)$ and (Level of use of fixed assets plus working capital $=0)=$ Class=MONEY LOSING COMPANY $(759.0 / 21.0)$

2. $($ EBIT $=0)$ and $($ Other results $=0)$ and $($ Financial result $=0)$ and (Income on working capital $=0)=$ Class=MONEY LOSING COMPANY $(290.0 / 40.0)$

3. (Number of days of payment of liabilities to suppliers $=1$ ) and $($ EBIT $=0)$ and (Income on working capital $=0)$ and (Net result rate before taxation $=0$ ) and (Liability turnover $=0)=$ Class=MONEY LOSING COMPANY $(10.0 / 3.0)$

\section{4. $($ EBIT $=1)=$ Class $=$ MONEY EARNING COMPANY $(1470.0 / 31.0)$}

Number of Rules: 4 (four)

Review 2. Inductive rules for the model of basic business indicators

Rule 1: The inductive rule reads that if EBIT is negative $=0$ and if the number of days of payment to suppliers is positive $=1$, and if the level of use of fixed assets plus working capital is a negative indicator, then 759 money losing companies are generated.

Rule 2: reads that if EBIT $=0$, if other results $=0$, if financial results $=0$ and if Income on working capital $=0$, then 290 money losing companies are generated.

Rule 3: If number of days of payment to suppliers $=1$, if EBIT $=0$, if Income on working capital $=0$, whereas net result rate before taxation $=0$ and if Liability turnover $=0$, then only 10 money losing companies are generated.

Rule 4: for EBIT =1, 1.968 money earning companies are generated.

\section{Application of the method of feature selection}

The results of the WEKA feature selection (2 class). The best subset is obtained by various methods of examining and evaluating of feature subsets and this subset gives the most accurate rules (trees). Some methods also give numerical scores for individual features.

The method called Relieff (each feature is evaluated separately) has given the following results: Evaluation model:10-fold cross-validation

Review 13.

\begin{tabular}{ccl}
\hline average merit & average rank & \multicolumn{1}{c}{ Feature } \\
\hline $0.387+-0.016$ & $1.1+-0.3$ & 27 EBIT \\
$0.362+-0.005$ & $1.9+-0.3$ & 33 Income on working capital \\
$0.325+-0.018$ & $3.5+-0.5$ & 33 number of days of payment of liabilities to suppliers \\
$0.328+-0.01$ & $3.5+-0.5$ & 26 EBITDA \\
$0.263+-0.014$ & $5+-0$ & 12 Turnover ratio of liabilities to suppliers \\
$0.2+-0.011$ & $6.5+-0.5$ & 25 Duration of cash conversion cycle \\
\hline
\end{tabular}


Using the method called Relieff, it has been estimated that the most important features are EBIT, Income on working capital, Number of days of payment to suppliers, EBITDA, Turnover ratio of liabilities to suppliers and Duration of cash conversion cycle. All other features have the value less than 0,2 of participation in the scale of significance of features.

\section{Validation of learning accuracy by the method of cross validation}

\begin{tabular}{||ccc||}
\hline \multicolumn{1}{|c|}{ Review 14.} \\
\hline Value & Recall & 1-Precision \\
\hline $\begin{array}{c}\text { Money earning } \\
\text { company }\end{array}$ & 0.9333 & 0.0245 \\
Money losing company & 0.9658 & 0.0915 \\
\hline
\end{tabular}

Application of the training set in order to evaluate the model performances has certain biases - deviations. In many cases, models remember the sample instead of training data (data over fitting). In order to eliminate this, we have applied a 10-fold cross validation.

The method of cross validation or rotary estimation divides accidentaly the set of examples $\mathrm{D}$ on $\kappa$ mutually disjoint subsets of the examples $\mathrm{D}_{1}, \mathrm{D}_{2} \ldots \mathrm{D}_{\mathrm{k}}$ whose size is approximately the same (Cherkassky V., Mulier F. M., 2007, Witten I. H., Frank E., 2005 ). Learning procedure and evaluation are repeated $k$ times, using one subset $D_{k}$ as a tight set every time. Total accuracy is calculated as the relation of the number of correct classifications and total number of examples in the set D.

Such estimation of prediction accuracy is a random number, which depends on the division of examples on subsets.

In the case of application of the Decision Tree, the overall cross validation error rate was from 0,0535 , to $3,006 \%$.

\section{Conclusion}

Analyzing money earning companies and money losing companies as a part of financial statements of business entities, which are the final exponents of the business result, we have obtained a cumulative indicator that business loss of the total economy was 12 billion euros in one year, while its value was reduced for $2 / 3$ in the next year. It should be added to this conclusion that the economy neither had significant investments nor an added value in the obseved years. In other words, net effect of the total economy increased constantly. The selected sample of 1000 business entities which we extracted from one calendar year, where it was estimated that the loss of the total economy was halved, served for detection where this effect of loss reduction disappears in financial statements in the following years, while the level of borrowing and other ratio indicators disclose completely opposite business effect of the total Serbian economy. This research and the conclusions we drew from it are based on the obtained results of the analyzed financial statements for 2010-2013, where we analyzed 500 money earning companies and 500 money losing companies respectively.

Disclosure of hidden losses in financial statements and manipulation with financial statements itself should be the essential job of forensic accountants as well as auditors. 
However, the aim of this conclusion is not to invite investigators, but to indicate the significance of application of quantitative analysis and to point out that hidden or manipulative actions may always be recongnized in the context of data observation through further course of the analysis. The predominant role of application of DM method, as a quantitatively oriented method, is to perform classification and prediction in the procedure of detection of hidden losses. In that sense, DM method is dominant and highly accurate - its accuracy is even up to $100 \%$. The methods we have used showed that EBIT ratio indicator is dominant, as it helps us, in combination with the indicators mentioned above, to determine whether a company is a money earning company or a money losing company.

On the other hand, insufficiency of other indicators, which are related to income and expenses that are not entered in financial statements, is the main disadvantage in the application of these methods in the domain of detection of hidden losses. On the contrary, qualitative analysis is based on decades of experience and it gives us more fruitful results. For illustration, there is no possibility for flexible treatment of certain public data, such as costs of currency depreciation, in which the state participated itself in 2008 and 2009, when it decided that entities might decide themselves when and how they would enter negative effects based on currency depreciation in financial income and loss, especially for 2010 and 2013. In this way, many companies delimited costs deliberately, which resulted in less reported total losses in 2012 and 2013. This phenomenon of manipulating with results continued to be applied in the period from 2010 to 2013. In the cases we have analyzed, financial effects affected total result in the way that it was corrected artificially, so that the loss of economy, amounting to 12 billion euros in 2010, was reduced to 4,7 billion euros in 2012 and 4,1 billion euros in 2013. This fact led us to use only quantitative analysis in order to detect the moments of manipulating with financial statement observing the result structure. Qualitative analysis has given us important answers to the question what manipulative elements are and where they are exposed in one way or another. Data mining analysis, besides its possibility of perfect selection, cannot give a good answer to the question in which direction business results go. This is because it relies on the published data that cannot be affected anymore. In the cases which we have analyzed in quantitative analysis through conscious revision correction or fixing of results, it has been explained where the exposed phenomenon occurs and who the carriers of such corrections are. Using the quantitative analysis, we have come to the conclusion that the phenomenon of manipulating with results and the manner in which this manipulation happens are characteristic for limited liability companies. This companies may take the risk, as they are responsible only to the amount of their founding deposit. It should not be ignored that the amounts of deposits of limited liability companies are always less than the turnover they have.

The data obtained in the DM analysis, which relies on ratio evaluations, may lead us to the wrong conclusion that there is a pattern in economic trends. We have seen in our analyses that EBIT which 1500 entities reported (for one calendar year), together with other ratio indicators, are extremely negative. This is confirmed in the following cases:

a) Liquidity evaluation - where an entity reports positive result, while it is insolvent according to all liquidity ratios and indicators;

b) Level of involvement of working capital is higher for money losing companies than money earning companies;

c) The reported collection rate for the entitites which reported EBITDA is more than 365 days and even up to 3 years for certain entitites, and the same situation is with money losing companies. 
These are the reasons which have led us to the conclusion that the manner of manipulating with data in financial statements is closely related to only one operation and one business item, this is, the result and changes of data are a corrected factor which participates with more than $7-15 \%$ of the value of correction in total results. We haven't neglected this fact and therefore we have concentrated our researches on the results after EBIT, as the indicators of extraordinary income appear after regular business dealings and they are closely related to the impact of an external factor. This is why quantitative analysis was conducted to discover the first step to detection of the manner and determination of the elements which may decide the fate of a business entity significantly, this is, whether it will be a money earning company, a money losing company or an independently exposed indicator on the market which may show the actual state of events.

Therefore, quantitative analysis and Data mining analysis have to be observed together, in order to define certain patterns. If these patterns do not exsist, this is if one of analyzed indicators does not have economic explanation of its appearance and disappearance, it is not the indicator, but the element for hiding and delaying of the fate of a certain business entity.

\section{References}

[1] Cherkassky V., Mulier F. M., Learning from Data: Concepts, Theory, and Methods, 2nd edition, John Wiley - IEEE Press, 2007.

[2] http://www.alsu.gov.rs/bap/code/navigate.jsp? Id=200. protal Public information, promotion and transparency and good practice in conducting of bankruptcy procedure

[3] Kantardzic, M. Data mining: concepts, models, methods, and algorithms'. Willey-IEEE Press.

[4] NBS,Statistical bulletin of economic trends in Serbia and data of NBS published in reports for 2010,2011, 2012 and 2013

[5] NBS, on the economy of the Republic of Serbia in 2010 , 2011, 2012 and 2013

[6] Quinlan J. R., "Bagging, Boosting and C4.5", in Proc. of AAAI-96 Fourteenth national Conference on Artificial Intelligence, Portland, OR, AAAI Press, Menlo Park, CA, 1996.

[7] Witten, F., „Data Mining: Practical machine learning tools and techniques “, 2nd edition, 2005, San Francisco, Morgan Kaufmann.

[8] Witten I. H., Frank E., Data Mining: Practical Machine Learning Tools and Techniques with Java Implementations, pp. 265-320, Morgan Kaufmann Publishers, 2005.

[9] Witten I.H., Frank E. Data Mining: Practical machine learning tools and techniques, 2nd edition. Morgan Kaufmann, San Francisco, 2005.

\section{Article history:}

- $\quad$ Received 20 November 2015

- $\quad$ Accepted 20 February 2016 